\title{
Can silicon (Si) fertilization influence the production and nutritional value of Urochloa Convert HD364?
}

\section{A fertilização por silício (Si) pode influenciar a produção e o valor nutricional da Urochloa Convert HD364?}

\author{
Jaqueline Rocha Wobeto Sarto ${ }^{1}$; Marcela Abbado Neres ${ }^{2}$; Caroline Daiane Nath ${ }^{3}$; \\ Doglas Bassegio ; Marcos Vinicius Mansano Sarto ${ }^{5 *}$
}

\begin{abstract}
Tropical soils are highly weathered, acidic, and low in silicon ( $\mathrm{Si}$ ) availability for plants. Si has been considered an essential nutrient for many grasses. Urochloa Convert HD364 is classified as a forage plant that accumulates $\mathrm{Si}$, but the accumulation of this nutrient in the leaf can influence qualitative characteristics, fiber quality, plant architecture, and development of forage. In this study, we aimed to evaluate the production and nutritive value of Urochloa hybrid cultivar Convert HD364 (CIAT 36087) grown from soils collected in the state of Paraná, Brazil. The experiment was carried out in a greenhouse using 8-L plastic pots and three types of soil. Treatments were arranged in a randomized block design in a $3 \times 5$ factorial: three soils [Rhodic Acrudox (Ox1), Rhodic Hapludox (Ox2) and Arenic Hapludult (Ult)] and five silicate rates $\left(0,1,2,4\right.$ and $6 \mathrm{Mg} \mathrm{ha}^{-1}$ of calcium/magnesium silicate), with four replications. Application of $\mathrm{CaSiO}_{3}$ to the soil increases the concentration of $\mathrm{Si}$ in the leaves of Urochloa Convert HD364. The dry matter, crude protein and mineral matter, fiber quality, and digestibility of Urochloa were not influenced by the increase in Si levels in the leaves until 45 days after seeding. Forty-five days after planting, $\mathrm{CaSiO}_{3}$ did not interfere with the growth characteristics and production of Urochloa Convert HD364. There is no evidence that the increased Si levels in the leaf affected the production and nutritive value, especially fiber quality of Urochloa Convert HD364 until 45 days after sedding.

Key words: Brachiaria. Calcium silicate. Digestibility. Fiber quality. Urochloa hybrid cultivar Convert HD364.
\end{abstract}

\section{Resumo}

Os solos tropicais são altamente intemperizados, ácidos e com baixa disponibilidade de silício ( $\mathrm{Si}$ ) para as plantas. O Si tem sido considerado um nutriente essencial para muitas gramíneas. A Urochloa Convert HD364 é classificada como planta forrageira que acumula $\mathrm{Si}$, mas o acúmulo desse nutriente na folha pode influenciar as características qualitativas, qualidade da fibra, arquitetura da planta e no desenvolvimento da forragem. Neste trabalho, objetivou-se avaliar a produção e o valor nutritivo da Urochloa cv. Convert HD364 (CIAT 36087), cultivado em três solos coletados no estado do Paraná,

${ }^{1}$ Dr $^{\mathrm{a}}$ em Zootecnia, Faculdade de Medicina Veterinária e Zootecnia, Universidade Estadual Paulista, UNESP, Botucatu, SP, Brasil. jaquelinerwsarto@gmail.com

2 Prof ${ }^{a}$, Departamento de Zootecnia, Universidade Estadual do Oeste do Paraná, UNIOESTE, Marechal Cândido Rondon, PR, Brasil. E-mail: marcela.neres@unioeste.br

3 Discente, Curso de Doutorado do Programa de Pós-Graduação em Zootecnia, UNIOESTE, Marechal Cândido Rondon, PR, Brasil. E-mail: karolynedayane@hotmail.com

4 Prof., Centro de Ciências Exatas e Tecnológicas, CCET, UNIOESTE, Cascavel, PR, Brasil. E-mail: doglas14@hotmail.com

5 Dr. em Agronomia, Faculdade de Ciências Agronômicas, FCA/ UNESP, Botucatu, SP, Brasil. E-mail: marcos.sarto28@gmail.com

* Author for correspondence 
Brasil. O experimento foi conduzido em casa de vegetação com vasos plásticos de $8 \mathrm{~L}$ e três tipos de solo. Os tratamentos foram arranjados em blocos casualizados em esquema fatorial $3 \times 5$ : três solos [Latossolo Vermelho distrférrico (Ox1), Latossolo Vermelho eutroférrico (Ox2) e Argisolo VermelhoAmarelo (Ult)] e cinco doses de silicato (0, 1, 2, 4 e $6 \mathrm{Mg} \mathrm{ha}^{-1}$ de silicato de cálcio / magnésio), com quatro repetições. A aplicação de $\mathrm{CaSiO}_{3}$ no solo aumenta a concentração de Si nas folhas de Urochloa Convert HD364. A matéria seca, proteína bruta, matéria mineral, qualidade da fibra e digestibilidade da Urochloa Convert HD364 não foram influenciadas pelo aumento nos teores de Si nas folhas até 45 dias após a semeadura. Quarenta e cinco dias após o plantio, o $\mathrm{CaSiO}_{3}$ não interferiu nas características de crescimento e produção do Urochloa Convert HD364. Não há evidências de que o aumento dos níveis de Si na folha tenha afetado a produção e o valor nutritivo, especialmente a qualidade da fibra, de Urochloa Convert HD364 até 45 dias após a semeadura.

Palavras-chave: Brachiaria. Silicato de cálcio. Digestibilidade. Qualidade da fibra. Urochloa cv. Convert HD364.

\section{Introduction}

Brazil has about 100 million hectares of cultivated pastures; many pastures have already been grazed on for more than 10 years, with approximately $60 \%$ of the areas in an advanced state of degradation (BARDUCCI et al., 2009). Over short and medium periods, more than 30 million hectares need to be recovered because they have already been degraded or show enhanced production decline (SANO et al., 2008). A reason for the resistance of Brachiaria grass (syn. Urochloa) in Cerrado soil may be its ability to absorb and accumulate $\mathrm{Si}$ in the epidermis of leaves, thereby reducing the toxic effects of aluminum (Al), manganese (Mn), and iron (Fe) and increasing phosphorus (P) availability (COCKER et al., 1998; KORNDÖRFER et al., 2006; SARTO et al., 2015). In addition, it is known that $\mathrm{Si}$ in Brachiaria (syn. Urochloa) reduces internal $\mathrm{CO}_{2}$ concentration and increases the efficiency of water use (SARTO et al., 2016).

Urochloa Convert HD364 is the first hybrid of Brachiaria marketed in Brazil, and it was developed from the crossing of three species of Urochloa ( $U$. brizantha $x U$. decumbens $x U$. ruziziensis). This cultivar is a perennial, semi-erect growth hybrid that can reach up to $1 \mathrm{~m}$ in height (ARGEL et al., 2007), also have characteristics of resistance to the spittlebug (Zulia entreriana, Deois fravopicta and Deois schac), to prolonged droughts, high temperatures, acid soils, besides responding well to grazing and nitrogen fertilization (RICAURTE et al., 2007).

Tropical soils are highly weathered, acidic, and low in Si availability for plants. Limestone has been predominantly used to correct soil acidity; however, alternate corrective materials such as silicates are available, and they increase soil $\mathrm{pH}$, provide $\mathrm{Ca}$ and $\mathrm{Mg}$, and neutralize toxic $\mathrm{Al}^{3+}$ and available $\mathrm{Si}$ (KORNDÖRFER et al., 2006; SARTO et al., 2014, 2015, 2017). Si has been considered an essential nutrient for many grasses, and Si concentration is higher in monocots than in dicots (VAN RAIJ, 1991). This results in several benefits for plants, especially greater tolerance to insect attack (EPSTEIN, 2001) and diseases (MARSCHNER, 1995), reduced sweating (DATNOFF et al., 2001; MARSCHNER, 1995), and a higher photosynthetic rate due to improvement in leaf architecture (DEREN, 2001). Also, Si helped to alleviate the toxic effects of $\mathrm{Al}^{+3}$ (SARTO et al., 2016). However, Si is still relatively unknown and rarely applied in agriculture.

Beneficial effects of silicate application on the crop development and yield has been confirmed in several crops such as rice (CARVALHO-PUPATTO et al., 2004), sugar cane (REIS et al., 2013), maize (CASTRO; CRUSCIOL, 2013) and wheat (SARTO et al., 2015; PROVANCE-BOWLEY et al., 2010), which are considered Si-accumulating species. In many cases, an increase in Si availability has increased crop development and yield, and this 
nutrient can indirectly influence some photosynthetic and biochemical aspects, especially in plants under biotic or abiotic stress conditions (MA; YAMAJI, 2006). Maximum growth and biomass accumulation in plants that received Si treatment are associated with changes in the plant architecture, making them erect, improving the angle of the leaves and light interception, avoiding excessive self-shading, delaying senescence, increasing the structural rigidity of tissues, improving photosynthesis, and reducing lodging (SARTO et al., 2016; GONG; CHEN, 2012; MA; YAMAJI, 2008). These beneficial effects are attributable to Si deposited in the cell walls of various plant organs (MA; YAMAJI, 2006) and other mechanisms. High deposition of Si in tissues results in a physical barrier that enhances the strength and rigidity of the tissues. Few studies have been conducted on the effects of Si on plant nutrition, and most of the studies reported aspects of wheat growth and the beneficial role of $\mathrm{Si}$ in resistance to biotic and abiotic stresses (RIZWAN et al., 2012; SARTO et al., 2014). In addition, the beneficial effects of $\mathrm{Si}$ are not always observed (DANN; MUIR, 2002).

Limestone is the most applied source for acidity correction in Brazil due to its price and capacity to increase fertilizer efficiency. Nevertheless, limestone is not a very soluble material and its dissociated components show limited mobility, usually restricting correction effects in uppermost soil layers, mainly under non-mobilized conditions of no-till (CASTRO; CRUSCIOL, 2013; SORATTO; CRUSCIOL, 2008).

However, other materials, such as steel corrective residues, have the same purpose and are viable, especially calcium silicate $\left(\mathrm{CaSiO}_{3}\right)$. Slag is used to correct soil acidity (SARTO et al., 2015), and it is also effective in providing Si to plants (SARTO et al., 2014, 2015, 2016; BARBOSA FILHO et al., 2004). However, increased Si concentration in leaves can influence the nutritional composition and quality and, thus, digestibility, of fodder plant fiber. In this study, we aimed to evaluate the production and nutritive value of Urochloa Convert HD364 grown in three soils treated with different $\mathrm{CaSiO}_{3}$ rates.

\section{Material and Methods}

\section{Study site description}

Pot experiments were performed in a greenhouse in Marechal Cândido Rondon, Paraná State, Brazil $\left(24^{\circ} 31^{\prime} \mathrm{S}, 54^{\circ} 01^{\prime} \mathrm{W}\right.$ and $420 \mathrm{~m}$ asl), where the environmental conditions were as follows: minimum and maximum mean air temperature of 18 and $36{ }^{\circ} \mathrm{C}$, respectively and mean air relative humidity of $65 \%$.

Soils

Surface samples $(0-0.2 \mathrm{~m})$ from three representative soils of the western region of Paraná State, Brazil, were selected for Si fertilization studies (Table 1). Physical and chemical properties of the soils were determined by adopting standard procedures, and some properties are listed in Table 2.

Soil $\mathrm{pH}$ in $0.01 \mathrm{~mol} \mathrm{\textrm {L } ^ { - 1 }} \mathrm{CaCl}_{2}$ solution was determined potentiometrically in a 1:2.5 (soil:solution) suspension by using a combined calomel-reference glass electrode and $\mathrm{pH}$ meter. Organic matter was quantified by oxidation with potassium dichromate in the presence of sulfuric acid (ROSSET et al., 2014, 2016), followed by titration with ammonium $\mathrm{Fe}$ (II) sulfate (EMBRAPA, 2009). Available $P$, exchangeable potassium (K), and cationic micronutrients $(\mathrm{Cu}, \mathrm{Zn}, \mathrm{Fe}$, and $\mathrm{Mn})$ were extracted using Mehlich-1 solution in a 1:10 (w:v) soil-to-extract solution ratio (EMBRAPA, 2009; SARTO et al., 2011); P was determined using colorimetry at $725-\mathrm{nm}$ wavelength, and $\mathrm{K}$ and micronutrients were determined using atomic absorption spectrophotometry. $\mathrm{Ca}$ and magnesium $(\mathrm{Mg})$ were extracted by $1 \mathrm{~mol} \mathrm{~L}^{-1} \mathrm{KCl}$ solution and determined using atomic absorption spectrophotometry. Cation exchange capacity (CEC) 
was estimated using the summation method (CEC $=$ $\mathrm{H}+\mathrm{Al}+\mathrm{Ca}+\mathrm{Mg}+\mathrm{K}$ ). Soluble Si was extracted by $0.5 \mathrm{~mol} \mathrm{~L}^{-1}$ acetic acid solution in a 1:10 (w:v) soil-to-extractant solution ratio (KORNDÖRFER et al., 1999) and determined by beta molybdosilicic complex formation with a spectrophotometer at 660-nm wavelength. Particle size analysis was performed using the pipette method (EMBRAPA, 2009), according to decantation speed of different soil particles after dispersion in $0.015 \mathrm{~mol} \mathrm{~L}^{-1}$ $\left(\mathrm{NaPO}_{3}\right)_{6} \cdot \mathrm{NaO} / 1.0 \mathrm{~mol} \mathrm{~L}^{-1} \mathrm{NaOH}$ by overnight shaking.

Table 1. Brazilian soil classification, approximate equivalence to soil taxonomy and sampling site of the three soils from Paraná State, Brazil.

\begin{tabular}{ccc}
\hline Soil & Brazilian soil classification $^{\dagger}$ & Soil taxonomy $^{\dagger \dagger}$ \\
\hline Ox1 & Eutroferric Red Latosol & Rhodic Acrudox \\
Ox2 & Distroferric Red Latosol & Rhodic Hapludox \\
Ult & Red-Yellow Argisol & Arenic Hapludult \\
\hline
\end{tabular}

${ }^{\dagger}$ According to EMBRAPA (2013). ${ }^{\dagger}$ USDA Soil Taxonomy (SOIL SURVEY STAFF, 2010).

Table 2. Some physical and chemical properties of the soils.

\begin{tabular}{lccc}
\hline \multirow{2}{*}{ Soil characteristics } & \multicolumn{2}{c}{ Soils } \\
\cline { 2 - 4 } Soil $\mathrm{pH}$ & 5.3 & Ox2 & Ult \\
Clay $\left(\mathrm{g} \mathrm{kg}^{-1}\right)$ & 550.0 & 5.1 & 6.2 \\
Silt $\left(\mathrm{g} \mathrm{kg}^{-1}\right)$ & 370.0 & 435.0 & 100.0 \\
Sand $\left(\mathrm{g} \mathrm{kg}^{-1}\right)$ & 80.0 & 35.0 & 45.0 \\
Organic matter $\left(\mathrm{g} \mathrm{kg}^{-1}\right)$ & 26.0 & 39.6 & 855.0 \\
Available $\mathrm{P}\left(\mathrm{mg} \mathrm{kg}^{-1}\right)$ & 37.1 & 22.5 & 22.0 \\
$\mathrm{H}+\mathrm{Al}\left(\mathrm{cmol}_{\mathrm{c}} \mathrm{kg}^{-1}\right)$ & 4.6 & 10.7 & 40.7 \\
Exchangeable Al $\left(\mathrm{cmol}_{\mathrm{c}} \mathrm{kg}^{-1}\right)$ & 0.0 & 2.4 & 2.0 \\
Exchangeable K $\left(\mathrm{cmol}_{\mathrm{c}} \mathrm{kg}^{-1}\right)$ & 0.15 & 0.20 & 0.0 \\
Calcium $\left(\mathrm{cmol}_{\mathrm{c}} \mathrm{kg}^{-1}\right)$ & 4.8 & 4.0 & 0.20 \\
Magnesium $\left(\mathrm{cmol}_{\mathrm{c}} \mathrm{kg}^{-1}\right)$ & 1.8 & 0.5 & 2.5 \\
CEC $\left(\mathrm{cmol}_{\mathrm{c}} \mathrm{kg}^{-1}\right)^{\dagger}$ & 11.4 & 15.4 & 0.7 \\
Soil base saturation $(\%)$ & 60.0 & 30.0 & 5.4 \\
Copper $\left(\mathrm{mg} \mathrm{kg}^{-1}\right)$ & 15.0 & 8.2 & 63.0 \\
Zinc $\left(\mathrm{mg} \mathrm{kg}^{-1}\right)$ & 132.0 & 110.0 & 9.9 \\
Iron $\left(\mathrm{mg} \mathrm{kg}^{-1}\right)$ & 41.1 & 35.4 & 247.0 \\
Manganese $\left(\mathrm{mg} \mathrm{kg}^{-1}\right)$ & 3.9 & 8.2 & 28.5 \\
Silicon $\left(\mathrm{mg} \mathrm{kg}^{-1}\right)$ & 19.3 & 15.8 & 5.4 \\
\hline
\end{tabular}

${ }^{\dagger}$ CEC: cation exchange capacity.

\section{Experimental design and treatments}

The experimental design was a $3 \times 5$ factorial in complete randomized blocks, with four replications.
Treatments consisted of three soils- $\mathrm{Ox} 1, \mathrm{Ox} 2$, and Ult - and wheat plants grown using 0 (control), 1, 2, 4 , and $6 \mathrm{tha}^{-1}$ of $\mathrm{CaSiO}_{3} / \mathrm{MgSiO}_{3}$. The silicate source 
used was AgroSilício ${ }^{\circledR}(10.5 \% \mathrm{Si}, 25 \% \mathrm{Ca}, 6 \% \mathrm{Mg}$, and $88 \%$ effective calcium carbonate equivalent (ECCE). The corrected soils were maintained for 15 days with water content at $60 \%$ field capacity. Then, the soils were placed in 8-L plastic pots and fertilized by applying $30 \mathrm{mg} \mathrm{kg}^{-1}$ of $\mathrm{N}$ (urea), $80 \mathrm{mg}$ $\mathrm{kg}^{-1}$ of $\mathrm{P}$ (simple superphosphate), and $60 \mathrm{mg} \mathrm{kg}^{-1}$ of $\mathrm{K}(\mathrm{KCl})$.

\section{Plant material}

Twenty seeds of the Urochloa hybrid cv. Convert HD364 (CIAT 36087) were sown, and they were thinned to three plants per pot nine days after seedling emergence. The pots were irrigated daily to maintain soil moisture at near field capacity.

\section{Production and nutritive value analyses}

The cut was made 45 days after sowing in the newly expanded leaf. It was evaluated the plant height, number of tillers, green leaves, stem diameter, fresh and dry matter of Urochloa Convert HD364. After drying in a forced air oven at $65^{\circ} \mathrm{C}$ for almost 72 hours, the samples were ground in a one mm sieve Willey mill and submitted to laboratory procedures to determine dry matter content (DM), mineral matter (MM) and crude protein (CP) according to AOAC (1990). Neutral detergent fiber (NDF), and acid detergent fiber (ADF) and lignin as reported by Van Soest et al. (1991). Hemicelluloses fractions (HEMI) calculated by difference: HEMI $=$ NDF - FDA. NDF digestibility was determined using a 2-stage fermentation technique according to Tilley and Terry (1963).

\section{Statistical analysis}

Original data were analyzed using analysis of variance and regression analysis, and significant equations with the highest coefficients of determination (Tukey test, $\mathrm{p} \leq 0.05$ ) were adjusted. All analyses were performed using Saeg 8.0 software for Windows (Statistical Analysis Software, UFV, Viçosa, MG, BRA).

\section{Results and Discussion}

\section{Silicon absorption by plant}

$\mathrm{Si}$ content in the leaves increased with the application of $\mathrm{CaSiO}_{3}$ to the soils (Figure 1). Increased from 32 to $40 \mathrm{~g} \mathrm{~kg}^{-1}$ in soil $\mathrm{Ox} 1,26$ to $37 \mathrm{~g} \mathrm{~kg}^{-1}$ in soil Ult, and 25 to $52 \mathrm{~g} \mathrm{~kg}^{-1}$ in soil $\mathrm{Ox} 2$, corresponding to an increase of $25 \%, 42 \%$, and $108 \%$ in the Si content in the leaves of Urochloa Convert HD364. Si absorption capacity is the primary determinant of whether Si cell uptake may be improved by transpiration. This is consistent with the results of Korndörfer et al. (2010), who observed higher absorption of $\mathrm{Si}$ in both Urochloa brizantha 'Marandu' and Urochloa brizantha 'Mombaça' because of silicate application. Pereira et al. (2004) highlighted the existence of close links between foliar concentrations and the Si dose applied. This increase may be related to the higher nutrient content in the soil (SARTO et al., 2014, 2015), and grasses such as Urochloa and Panicum are classified as accumulators because of their high capacity for accumulating Si (MA et al., 2001). The increase in silica content in the plant by the addition of $\mathrm{CaSiO}_{3}$ is consistent with the results of other studies on Si (SARTO et al., 2015; KORNDÖRFER et al., 1999).

\section{Nutritional value of Urochloa Convert HD364}

The dry matter, mineral matter, and crude protein of Urochloa Convert HD364 were not affected by the $\mathrm{CaSiO}_{3}$ rates applied to the Ox1, Ult, and Ox2 soils (Table 3). Differences were observed only in relation to the type of soil for dry and mineral matter and crude protein of Urochloa Convert HD364. Faria et al. (2008) studied the application of $\mathrm{CaSiO}_{3}$ to Rhodic Hapludox in which Marandu grass (Urochloa brizantha 'Marandu') was grown and found no effects of soil correction on the chemical 
composition of the forage. The high Si content in the leaves did not affect the chemical composition of Urochloa Convert HD364. Corroborating with the results observed in the present study, the high Si content in the leaf, did not affect the chemical composition of Urochloa Convert HD364. The plant age at the time of cutting (45 days) with the newly expanded leaf may have affected the result, more research should be conducted with different cuts.

Figure 1. Mean values silicon leaf $(\mathrm{Si})$ in Urochloa Convert HD364 affected by calcium silicate rates in soils: Ox1 $(-)$, Ult (---) and $\mathrm{Ox} 2(--){ }^{* *}$ and ${ }^{*}$ significant at $1 \%$ and $5 \%$ probability, respectively, by $\mathrm{F}$ test; ${ }^{\text {ns }}$ not significant.

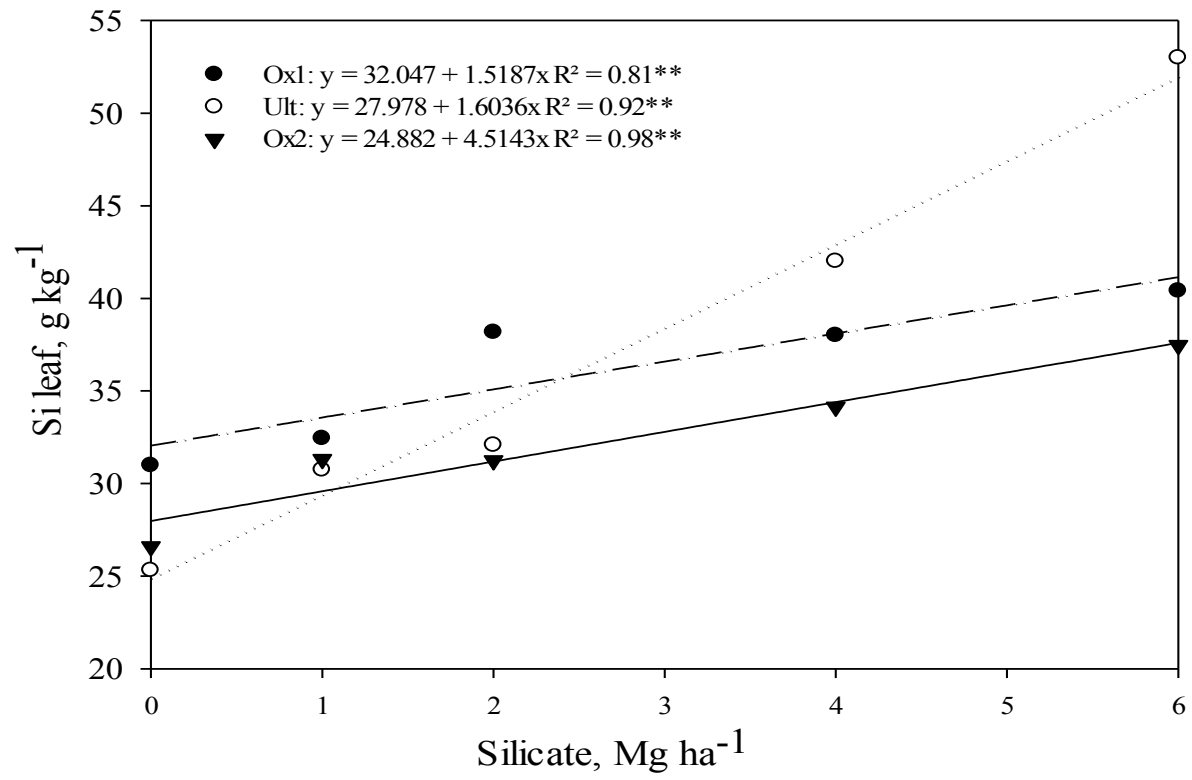

Table 3. Mean of dry matter, mineral matter and crude protein in Urochloa Convert HD364 affected by calcium silicate rates.

\begin{tabular}{|c|c|c|c|c|c|c|c|c|c|}
\hline \multirow[b]{2}{*}{ Silicate } & \multicolumn{3}{|c|}{ Dry Matter (\%) } & \multicolumn{3}{|c|}{ Mineral Matter (\%) } & \multicolumn{3}{|c|}{ Crude Protein $(\%)$} \\
\hline & Ox1 & Ult & Ox2 & Ox1 & Ult & Ox2 & Ox1 & Ult & Ox2 \\
\hline $\mathrm{Mg} \mathrm{ha}^{-1}$ & & - & & 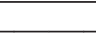 & $-\%$ & 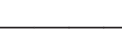 & 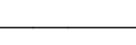 & ${ }^{-}$ & \\
\hline 0 & 17.26 & 21.92 & 14.50 & 8.25 & 7.45 & 8.10 & 15.32 & 11.37 & 17.46 \\
\hline 1 & 16.93 & 19.24 & 14.35 & 8.95 & 7.88 & 8.03 & 16.83 & 11.88 & 20.09 \\
\hline 2 & 16.98 & 23.26 & 15.13 & 8.29 & 8.06 & 8.29 & 14.08 & 11.25 & 18.15 \\
\hline 4 & 16.98 & 17.81 & 13.83 & 8.79 & 8.43 & 8.37 & 14.12 & 11.17 & 18.41 \\
\hline 6 & 17.32 & 23.24 & 16.62 & 8.60 & 8.21 & 8.47 & 14.79 & 10.78 & 17.09 \\
\hline \multirow[t]{2}{*}{ Mean } & $16.67 \mathrm{~b}$ & $19.60 \mathrm{a}$ & $17.33 \mathrm{ab}$ & $8.62 \mathrm{a}$ & $8.01 \mathrm{~b}$ & $8.20 \mathrm{ab}$ & $14.83 \mathrm{ab}$ & $13.01 \mathrm{~b}$ & $16.70 \mathrm{a}$ \\
\hline & & & & & F value & 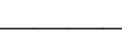 & 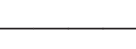 & - & \\
\hline Soil & & $3.34 *$ & & & $4.19 *$ & & & $9.24 * *$ & \\
\hline Rate & & $1.25^{\mathrm{ns}}$ & & & $1.31^{\mathrm{ns}}$ & & & $1.07^{\mathrm{ns}}$ & \\
\hline Soil*Rate & & $0.45^{\mathrm{ns}}$ & & & $0.72^{\mathrm{ns}}$ & & & $0.33^{\mathrm{ns}}$ & \\
\hline $\mathrm{CV}(\%)$ & & 21.0 & & & 8.26 & & & 18.27 & \\
\hline
\end{tabular}

** and $*$ significant at $1 \%$ and $5 \%$ probability, respectively, by $\mathrm{F}$ test; ${ }^{\mathrm{ns}}$ not significant. Means followed by the same lowercase letter on the line do not differ statistically by $5 \%$ Tukey test. 
Also, NDF, ADF, and hemicellulose were not affected by the application of $\mathrm{CaSiO}_{3}$ to the Ox1, Ult, and Ox2 soils (Table 4). Santana et al. (2010a) evaluated the nutritional value of Urochloa decumbens in soil amended with different rates of limestone and silicate and found that the nutritional composition of Urochloa decumbens, assessed using NDF and ADF, was not affected by acidity correction, except in the third cut where the application of lime resulted in a higher NDF content.

Table 4. Mean of neutral detergent fiber (NDF), acidic detergent fiber (ADF) and hemicellulose of Urochloa Convert HD364 affected to calcium silicate rates.

\begin{tabular}{|c|c|c|c|c|c|c|c|c|c|}
\hline \multirow[b]{2}{*}{ Silicate } & \multicolumn{3}{|c|}{ NDF } & \multicolumn{3}{|c|}{$\mathrm{ADF}$} & \multicolumn{3}{|c|}{ Hemicellulose } \\
\hline & Ox1 & Ult & $\mathrm{O} 2$ & Ox1 & Ult & Ox2 & Ox1 & Ult & Ox2 \\
\hline $\mathrm{Mg} \mathrm{ha}^{-1}$ & & & & & $\%$ & & & - & \\
\hline 0 & 46.38 & 52.80 & 48.31 & 29.63 & 29.83 & 31.65 & 16.76 & 22.96 & 16.66 \\
\hline 1 & 44.41 & 48.38 & 46.59 & 28.13 & 28.57 & 28.58 & 16.28 & 21.69 & 18.01 \\
\hline 2 & 47.49 & 51.33 & 47.27 & 29.77 & 28.66 & 29.90 & 17.73 & 22.67 & 17.37 \\
\hline 4 & 48.54 & 51.77 & 46.53 & 32.28 & 30.60 & 30.26 & 16.26 & 21.17 & 16.26 \\
\hline \multirow[t]{2}{*}{6} & 46.79 & 51.15 & 50.42 & 30.70 & 31.68 & 32.78 & 16.09 & 19.47 & 17.64 \\
\hline & \multicolumn{6}{|c|}{ F value } & & - & \\
\hline Soil & \multicolumn{3}{|c|}{$3.16^{\mathrm{ns}}$} & \multicolumn{3}{|c|}{$1.74^{\mathrm{ns}}$} & \multicolumn{3}{|c|}{$1.13^{\text {ns }}$} \\
\hline Rate & \multicolumn{3}{|c|}{$1.41^{\mathrm{ns}}$} & \multicolumn{3}{|c|}{$2.41^{\mathrm{ns}}$} & \multicolumn{3}{|c|}{$0.50^{\text {ns }}$} \\
\hline Soil*Rate & \multicolumn{3}{|c|}{$0.33^{\text {ns }}$} & \multicolumn{3}{|c|}{$0.42^{\text {ns }}$} & \multicolumn{3}{|c|}{$0.43^{\mathrm{ns}}$} \\
\hline $\mathrm{CV}(\%)$ & \multicolumn{3}{|c|}{7.17} & \multicolumn{3}{|c|}{9.62} & \multicolumn{3}{|c|}{16.94} \\
\hline
\end{tabular}

** and $*$ significant at $1 \%$ and $5 \%$ probability, respectively, by $\mathrm{F}$ test; ${ }^{\text {ns }}$ not significant. Means followed by the same lowercase letter on the line do not differ statistically by $5 \%$ Tukey test.

Santana et al. (2010b) evaluated the effects of two sources (limestone and silicate) and rates of lime on the nutritional composition, tillering, and dry matter production of Mombaça grass and noted that the nutritional value of the forage was not influenced by the correctives and rates used. Plants take up Si in the form of silicic acid, which is transported to the shoot, and, after the loss of water, it is polymerized as silica gel on the surface of leaves and stems (MA et al., 2001). Because Si is deposited in the cell wall, accumulation of $\mathrm{Si}$ keeps the leaves upright and increases resistance to lodging; an increase in the fiber ratio was expected in the treatments in which silicate was used as a concealer, especially considering the high ratio of ADF content to the digestibility of food. However, this hypothesis was not confirmed. The plant age at the time of cutting (45 days) with the newly expanded leaf may have affected the result, more research should be conducted with different cuts.

The digestibility of the forage was not significantly influenced by the dose and type of soil, indicating that the addition of up to $6 \mathrm{Mg} \mathrm{ha}^{-1}$ of $\mathrm{CaSiO}_{3}$ to the soil did not affect the digestibility of Convert HD364 until 45 days (Table 5). Even with the increase in Si content in the sheet (Figure 1), digestibility was not affected, probably because the lignin concentration was not affected by silicate, and the leaves were young. According to Fukushima and Paneto (1995), a lignin is associated with a break in the nutrient digestion of the fraction fibrous food and, considering that the maturity of the plants promotes increased lignin content, decreased nutritional value of mature plants. 
Santana et al. (2010a) observed that the the silicate. The NDF increased from the first to the nutritional composition of Urochloa decumbens, assessed using NDF and ADF, was not affected by acidity correction, except in the third cut in the third cut, whereas ADF showed the opposite trend; this indicated lower degradability with increasing lime application provided higher NDF content in cutting interval structures.

Table 5. Mean of digestibility and lignin of Urochloa Convert HD364 affected to calcium silicate rates.

\begin{tabular}{|c|c|c|c|c|c|c|}
\hline \multirow[b]{2}{*}{ Silicate } & \multicolumn{3}{|c|}{ Digestibility } & \multicolumn{3}{|c|}{ Lignin } \\
\hline & Ox1 & Ult & $\mathrm{Ox} 2$ & Ox1 & Ult & Ox2 \\
\hline $\mathrm{Mg} \mathrm{ha}^{-1}$ & \multicolumn{5}{|c|}{ - $\%$} & \\
\hline 0 & 87.70 & 88.38 & 88.14 & 6.00 & 3.77 & 5.10 \\
\hline 1 & 88.29 & 88.37 & 88.41 & 5.52 & 3.89 & 5.21 \\
\hline 2 & 88.05 & 90.29 & 88.72 & 6.19 & 3.55 & 5.08 \\
\hline 4 & 88.98 & 89.67 & 87.68 & 6.15 & 4.06 & 3.56 \\
\hline 6 & 86.80 & 88.85 & 86.74 & 6.13 & 3.15 & 4.08 \\
\hline \multirow[t]{2}{*}{ Mean } & 87.96 & 89.11 & 87.94 & $6.00 \mathrm{a}$ & $3.68 \mathrm{~b}$ & $4.61 \mathrm{~b}$ \\
\hline & \multicolumn{6}{|c|}{$\mathrm{F}$ value } \\
\hline Soil & \multicolumn{3}{|c|}{$0.55^{\mathrm{ns}}$} & \multicolumn{3}{|c|}{$14.41 * *$} \\
\hline Rate & \multicolumn{3}{|c|}{$1.11^{\mathrm{ns}}$} & \multicolumn{3}{|c|}{$0.33^{\text {ns }}$} \\
\hline Soil*Rate & \multicolumn{3}{|c|}{$0.20^{\mathrm{ns}}$} & \multicolumn{3}{|c|}{$0.63^{\mathrm{ns}}$} \\
\hline $\mathrm{CV}(\%)$ & \multicolumn{3}{|c|}{3.22} & \multicolumn{3}{|c|}{28.8} \\
\hline
\end{tabular}

\section{Production components}

The plant height, number of tillers, number of green leaves, stem diameter, fresh mass production, and dry matter Urochloa Convert HD364 were not affected by the $\mathrm{CaSiO}_{3}$ rates in the Ox1, Ult, and Ox2 soils (Tables 6 and 7). Although accumulation of $\mathrm{Si}$ was found in the leaves because of the application of Si, this difference was not sufficient to determine the vegetative development of the forage. This was consistent with the results obtained by Korndörfer et al. (2010), who observed that the supply of $\mathrm{CaSiO}_{3}$ promoted additions of $\mathrm{Si}$ foliar on the sheet but did not alter dry matter production by Urochloa brizantha 'Marandu' and Panicum maximum 'Mombaça'. 
Table 6. Mean of plant height, number of tillers and green leaves of Urochloa Convert HD364 affected to calcium silicate rates.

\begin{tabular}{|c|c|c|c|c|c|c|c|c|c|}
\hline \multirow[b]{2}{*}{ Silicate } & \multicolumn{3}{|c|}{ Plant height } & \multicolumn{3}{|c|}{ Number of Tillers } & \multicolumn{3}{|c|}{ Green leaves } \\
\hline & Ox1 & Ult & $\mathrm{Ox} 2$ & Ox1 & Ult & Ox2 & Ox1 & Ult & $\mathrm{Ox} 2$ \\
\hline $\mathrm{Mg} \mathrm{ha}^{-1}$ & \multicolumn{4}{|c|}{$\mathrm{cm}$} & \multicolumn{4}{|c|}{$-\mathrm{n}^{0}-$} & \\
\hline 0 & 34.96 & 32.92 & 40.83 & 8.08 & 7.33 & 7.17 & 4.50 & 4.58 & 4.08 \\
\hline 1 & 37.50 & 28.79 & 41.33 & 8.08 & 6.08 & 7.17 & 4.88 & 4.42 & 4.25 \\
\hline 2 & 31.07 & 33.46 & 38.67 & 6.83 & 5.58 & 6.33 & 4.50 & 4.75 & 4.33 \\
\hline 4 & 34.38 & 32.83 & 41.92 & 7.25 & 6.58 & 5.00 & 4.83 & 4.04 & 4.33 \\
\hline \multirow[t]{2}{*}{6} & 32.25 & 35.25 & 39.42 & 7.42 & 6.42 & 7.42 & 4.92 & 5.00 & 3.83 \\
\hline & \multicolumn{9}{|c|}{$\mathrm{F}$ value } \\
\hline Soil & \multicolumn{3}{|c|}{$0.09^{\text {ns }}$} & \multicolumn{3}{|c|}{$0.36^{\mathrm{ns}}$} & \multicolumn{3}{|c|}{$0.31^{\mathrm{ns}}$} \\
\hline Rate & \multicolumn{3}{|c|}{$0.17^{\mathrm{ns}}$} & \multicolumn{3}{|c|}{$2.13^{\text {ns }}$} & \multicolumn{3}{|c|}{$0.24^{\mathrm{ns}}$} \\
\hline Soil*Rate & \multicolumn{3}{|c|}{$0.51^{\mathrm{ns}}$} & \multicolumn{3}{|c|}{$1.09^{\mathrm{ns}}$} & \multicolumn{3}{|c|}{$0.15^{\mathrm{ns}}$} \\
\hline $\mathrm{CV}(\%)$ & \multicolumn{3}{|c|}{18.21} & \multicolumn{3}{|c|}{19.6} & \multicolumn{3}{|c|}{13.17} \\
\hline
\end{tabular}

** and * significant at $1 \%$ and $5 \%$ probability, respectively, by $\mathrm{F}$ test; ${ }^{\text {ns }}$ not significant. Means followed by the same lowercase letter on the line do not differ statistically by $5 \%$ Tukey test.

Table 7. Mean of stem diameter, fresh and dry matter of Urochloa Convert HD364 affected to calcium silicate rates.

\begin{tabular}{|c|c|c|c|c|c|c|c|c|c|}
\hline \multirow[b]{2}{*}{ Silicate } & \multicolumn{3}{|c|}{ Stem Diameter } & \multicolumn{3}{|c|}{ Fresh Mass } & \multicolumn{3}{|c|}{ Dry Matter } \\
\hline & Ox1 & Ult & Ox2 & Ox1 & Ult & Ox2 & Ox1 & Ult & Ox2 \\
\hline $\mathrm{Mg} \mathrm{ha}^{-1}$ & \multicolumn{3}{|c|}{$\longrightarrow \mathrm{mm}$} & \multicolumn{6}{|c|}{ g per pot } \\
\hline 0 & 4.74 & 5.07 & 4.73 & 65.20 & 50.50 & 96.26 & 19.28 & 18.22 & 22.53 \\
\hline 1 & 4.69 & 4.46 & 4.25 & 59.85 & 48.39 & 73.29 & 18.05 & 17.22 & 18.78 \\
\hline 2 & 4.96 & 4.70 & 4.27 & 67.73 & 39.67 & 78.94 & 19.49 & 16.40 & 20.09 \\
\hline 4 & 4.85 & 4.64 & 4.69 & 62.38 & 53.00 & 84.43 & 18.49 & 16.92 & 20.04 \\
\hline \multirow[t]{2}{*}{6} & 5.17 & 4.65 & 4.73 & 63.38 & 46.06 & 71.42 & 18.95 & 17.83 & 19.74 \\
\hline & \multicolumn{9}{|c|}{$F$ F value } \\
\hline Soil & \multicolumn{3}{|c|}{$1.31^{\mathrm{ns}}$} & \multicolumn{3}{|c|}{$0.77^{\mathrm{ns}}$} & \multicolumn{3}{|c|}{$0.14^{\mathrm{ns}}$} \\
\hline Rate & \multicolumn{3}{|c|}{$1.39^{\mathrm{ns}}$} & \multicolumn{3}{|c|}{$1.09^{\mathrm{ns}}$} & \multicolumn{3}{|c|}{$1.22^{\mathrm{ns}}$} \\
\hline Soil*Rate & \multicolumn{3}{|c|}{$0.72^{\text {ns }}$} & \multicolumn{3}{|c|}{$0.56^{\mathrm{ns}}$} & \multicolumn{3}{|c|}{$0.56^{\text {ns }}$} \\
\hline $\mathrm{CV}(\%)$ & \multicolumn{3}{|c|}{9.91} & \multicolumn{3}{|c|}{23.17} & \multicolumn{3}{|c|}{12.36} \\
\hline
\end{tabular}

** and $*$ significant at $1 \%$ and $5 \%$ probability, respectively, by $\mathrm{F}$ test; ${ }^{\mathrm{ns}}$ not significant. Means followed by the same lowercase letter on the line do not differ statistically by $5 \%$ Tukey test.

Sávio et al. (2011), studied the effects of different sources of $\mathrm{Si}$ on the agronomic characteristics and leaf Si content of Urochloa decumbens 'Basilisk' and Panicum maximum 'Mombaça' on Rhodic Acrudox, observed different accumulations of $\mathrm{Si}$ in the leaves because of Si application in the first cut. However, these differences were not enough to affect the vegetative growth of the forage, according to the production of fresh manure and plant height. 


\section{Conclusions}

Application of $\mathrm{CaSiO}_{3}$ to the soil increases the concentration of $\mathrm{Si}$ in the leaves of Urochloa Convert HD364. The dry matter, crude protein and mineral matter, fiber quality, and digestibility of Urochloa Convert HD364 were not influenced by the increase in Si levels in the leaves in the first cut. Forty-five days after planting, $\mathrm{CaSiO}_{3}$ did not interfere with the growth characteristics and production of Urochloa Convert HD364. There is no evidence that the increased Si levels in the leaf affected the production and nutritive value, especially fiber quality, of Urochloa until 45 days after planting.

\section{References}

ARGEL, P. J.; MILES, J. W.; GUIOT, J. D.; CUADRADO, H.; LASCANO, C. E. Cultivar Mulato II (Brachiaria híbrida CIAT 36087): gramínea de alta qualidade e produção forrageira, resistente às cigarrinhas e adaptada a solos tropicais ácidos. Cali: CIAT, 2007, 22 p.

ASSOCIATION OF OFFICIAL ANALYTICAL CHEMISTS - AOAC. Official Methods of Analysis. 15 $5^{\text {th }}$ ed. Arlington, 1990.

BARBOSA FILHO, M. P.; ZIMMERMANN, F. J. P.; SILVA, O. F. Influência da escória silicatada na acidez do solo e na produtividade de grãos do arroz de terras altas. Ciência e Agrotecnologia, Lavras, v. 28, n. 28, p. 323-331, 2004.

BARDUCCI, R. S.; COSTA, C.; CRUSCIOL, C. A. C.; BORGHI, E.; PUTAROV, T. C.; SARTI, L. Produção de Brachiaria brizantha e Panicum maximum com milho e adubação nitrogenada. Archivos de Zootecnia, Córdoba, v. 58, n. 222 , p. 211-222, 2009.

CARVALHO-PUPATTO, J. G.; BÜLL, L. T.; CRUSCIOL, C. A. C. Atributos químicos do solo, crescimento radicular e produtividade do arroz de acordo com a aplicação de escórias. Pesquisa Agropecuária Brasileira, Brasília, v. 39, n. 12, p. 1213-1218, 2004.

CASTRO, G. S. A.; CRUSCIOL, C. A. C. Effects of superficial liming and silicate application on soil fertility and crop yield under rotation. Geoderma, Amsterdam, v. 195-196, p. 234-242, 2013. DOI: 10.1016/j. geoderma.2012.12.006

COCKER, K. M.; EVANS, D. E.; HODSON, M. J. The amelioration of aluminum toxicity by silicon in higher plants: solutions chemistry or in plant mechanism? Physiologia Plantarum, v. 104, n. 4, p. 608-614, 1998. DOI: 10.1034/j.1399-3054.1998.1040413.x

DANN, E. K.; MUIR, S. Peas growth in media with elevated plant available silicon levels have higher activities of chitinase and $\alpha-1,3$ glucanase, are less susceptible to a fungal leaf spot pathogen and accumulate more foliar silicon. Australasian Plant Pathology, v. 31, n. 1, p. 9-13, 2002. DOI: 10.1071/AP01047

DATNOFF, L. E.; SNYDER, G. H.; KORNDÖRFER, G. H. Silicon in agriculture. Amsterdam: Elsevier Science, 2001. $403 \mathrm{p}$.

DEREN, C. Plant genotypes, silicon concentration and silicon related responses. In: DATNOFF, L. E.; SNYDER, G. H.; KORNDÖRFER, G. H. Silicon in agriculture. Elsevier, 2001. v. 8, p. 149-158.

DEREN, C. Manual de análises químicas de solos, plantas e fertilizantes. 2. ed. Brasília: Informação Tecnológica, 2009. 628 p.

DEREN, C. Sistema brasileiro de classificação de solos. 3.ed. Rio de Janeiro: Embrapa Solos, 2013. 353 p.

EPSTEIN, E. Silicon in plants: facts vs concepts. In: DATNOFF, L. E.; SNYDER, G. H.; KORNDÖRFER, G. H. (Ed.). Silicon in agriculture. Elsevier Science, 2001. p. 1-15.

FARIA, L. de A.; LUZ, P. H. de C.; RODRIGUES, R. C.; HERLING, V. R.; MACEDO, F. B. Efeito residual da silicatagem no solo e na produtividade do capimmarandu sob pastejo. Revista Brasileira de Ciência do Solo, Viçosa, MG, v. 32, n. 3, p. 1209-1216, 2008.

FUKUSHIMA, R. S.; PANETO, J. C. C. A lignina e o valor nutritivo das plantas forrageiras: uma revisão. Zootecnia, v. 33, p. 29-39, 1995.

GONG, H.; CHEN, K. The regulatory role of silicon on water relations, photosynthetic gas exchange, and carboxylation activities of wheat leaves in field drought conditions. Acta Physiologiae Plantarum, Cracóvia,, v. 34, n. 4, p. 1-6, 2012. DOI: 10.1007/s11738-012-0954-6

KORNDÖRFER, G. H.; COELHO, N. M.; SNYDER, D. H.; MIZUTANI, C. T. Evaluation of silicon extraction methods for soils under upland rice. Revista Brasileira de Ciência do Solo, Viçosa, MG, v. 23, n. 1, p. 101-103, 1999.

KORNDÖRFER, G.; SNYDER, G. H.; ULLOA, M.; POWELL, G.; DATNOFF, L. E. Calibration of soil and plant silicon analysis for rice production. Journal of Plant Nutrition, v. 24, n. 7, p. 1071-1084, 2006. DOI: 10.1081/PLN-100103804 
KORNDÖRFER, P. H.; SILVA, G. C.; TEIXEIRA, I. R.; SILVA, A. G.; FREITAS, R. S. Silicon fertilization effect on grasses and soil chemical properties. Pesquisa Agropecuária Tropical, Goiânia, v. 40, n. 2, p. 119-125, 2010. DOI: 10.1007/978-1-4612-2894-3 5

MA, J. F.; MIYAKE, Y.; TAKAHASHI, E. Silicon as a beneficial element for crop plants. In: DATNOFF, L. E.; SNEDER, G. H.; KORNDÖRFER, G. H. (Ed.). Silicon in agriculture. Amsterdam: Elsevier Science, 2001. p. 17-39.

MA, J. F.; YAMAJI, N. Functions and transport of silicon in plants. Cellular and Molecular Life Science, Switzerland, v. 65 , n. 19 , p. $3049-3057,2008$. DOI: 10.1007/s00018-008-7580-X

MA, J. F.; YAMAJI, N. Silicon uptake and accumulation in higher plants. Trends in Plant Science, Cambridge, v. 11, n. 8, p. 392-397, 2006. DOI: 10.1016/j. tplants.2006.06.007

MARSCHNER, H. Mineral nutrition of higher plants. $2^{\text {th }}$ ed. London: Academics Press, 1995. 889 p.

PEREIRA, H. S.; KORNDÖRFER, G. H.; VIDAL, A. A.; CAMARGO, M. S. Silicon sources for rice crop. Scientia Agricola, Piracicaba, v. 61, n. 5, p. 522-528, 2004. DOI: $10.1590 / \mathrm{S} 0103-90162004000500010$

PROVANCE-BOWLEY, M. C.; HECKMAN, J. R.; DURNER, E. F. Calcium silicate suppresses powdery mildew and increases yield of field grown wheat. Soil Science Society of America Journal, Madison, v. 74, n. 5, p. 1652-1661, 2010. DOI: 10.2136/sssaj2010.0134

REIS, J. J. D.; ALOVISI, A. M. T.; FERREIRA, J. A. A.; ALOVISI, A. A.; GOMES, C. F. Atributos químicos do solo e produção da cana-de-açúcar em resposta ao silicato de cálcio. Revista de Ciências Agrárias, Lisboa, v. 36, n. 1, p. 3-9, 2013.

RICAURTE, J.; RAO, I. M.; MENJIVAR, J. C. Estrageias de enraizamiento de genotipo Brachiaria en suelos ácidos y de baja fertilidad en Colombia. Acta Agronómica, Palmira, v. 56, n. 3, p. 107-115, 2007. DOI:

RIZWAN, M.; MEUNIERM, J.-D.; MICHE, H.; KELLER, C. Effect of silicon on reducing cadmium toxicity in durum wheat (Triticum turgidum L. cv. Claudio W.) grown in a soil with aged contamination. Journal of Hazardous Materials, v. 209-210, p. 326-334, 2012. DOI: $10.1016 /$ j.jhazmat.2012.01.033

ROSSET, J. S.; LANA, M. C.; PEREIRA, M. G.; SCHIAVO, J. A.; RAMPIM, L.; SARTO, M. V. M. Frações químicas e oxidáveis da matéria orgânica do solo sob diferentes sistemas de manejo, em Latossolo Vermelho. Pesquisa Agropecuária Brasileira, Brasília, v. 51 , n. 9 , p. $1529-1538,2016$. DOI: $10.1590 / \mathrm{S} 0100-$

\section{X2016000900052}

ROSSET, J. S.; LANA, M. C.; PEREIRA, M. G.; SCHIAVO, J. A.; RAMPIM, L.; SARTO, M. V. M.; SEIDEL, E. P. Carbon stock, chemical and physical properties of soils under management systems with different deployment times in western region of Paraná, Brazil. Semina: Ciências Agrárias, Londrina, v. 35, n. 6, p. $3053-3072$, 2014. DOI: $10.5433 / 1679-0359.2014 v 35$ n6p3053

SANO, E. E.; ROSA, R.; BRITO, J. L. S.; FERREIRA, L. G. Mapeamento semidetalhado do uso da terra no bioma Cerrado. Pesquisa Agropecuária Brasileira, Brasília, v. 43, n. 1, p. 153-156, 2008.

SANTANA, G. S.; BIANCHI, P. P. M.; MORITA, I. M.; ISEPON, O. J.; FERNANDES, F. M. Produção e composição bromatológica da forragem do capimmombaça (Panicum maximum Jacq.), submetidos a diferentes fontes e doses de corretivo de acidez. Semina: Ciências Agrárias, Londrina, v. 31, n. 1, p. 241-246, 2010b.

SANTANA, G. S.; MORITA, I. M.; BIANCHI, P. P. M.; FERNANDES, F. M.; ISEPON, O. J. Atributos químicos, produção e qualidade do capim braquiária em solos corrigidos com calcário e escória silicatada. Revista Ceres, Viçosa, MG, v. 57, n. 3, p. 377-382, 2010a.

SARTO, M. V. M.; LANA, M. C.; RAMPIM, L.; ROSSET, J. S.; INAGAKI, A. M.; BASSEGIO, D. Effects of silicon $(\mathrm{Si})$ fertilization on gas exchange and production in Brachiaria. Australian Journal of Crop Science, v. 10, n. 3, p. 307-313, 2016.

SARTO, M. V. M.; LANA, M. C.; RAMPIM, L.; ROSSET, J. S.; WOBETO, J. R. Effects of silicate application on soil fertility and wheat yield. Semina: Ciências Agrárias, Londrina, v. 36, n. 6, p. 4071-4082, 2015. Supplement 2. DOI: 10.5433/1679-0359.2015v36n6Sup12p4071

SARTO, M. V. M.; LANA, M. C.; RAMPIM, L.; ROSSET, J. S.; WOBETO, J. R.; ECCO, M.; BASSEGIO, D.; COSTA, P. F. Effect of silicate on nutrition and yield of wheat. African Journal of Agricultural Research, v. 9, n. 11, p. 956-962, 2014.

SARTO, M. V. M.; SARTO, J. R. W.; RAMPIM, L.; ROSSET, J. S.; BASSEGIO, D.; INAGAKI, A. M.; COSTA, P. F. Wheat phenology and yield under drought: a review. Australian Journal of Crop Science, v. 11, n. 8, p. 941-946, 2017.

SARTO, M. V. M.; STEINER, F.; LANA, M. do C. Assessment of micronutrient extractants from soils of Paraná, Brazil. Revista Brasileira de Ciência do Solo, Viçosa, MG, v. 35, n. 6, p. 2093-2103, 2011. DOI: 10.1590/S0100-06832011000600024 
SÁVIO, F. L.; SILVA, G. C.; TEIXEIRA, I. R.; BORÉM, A. Produção de biomassa e conteúdo de silício em gramíneas forrageiras sob diferentes fontes de silicato. Semina: Ciências Agrárias, Londrina, v. 32, n. 1, p. 103110, 2011.

SOIL SURVEY STAFF. Keys to soil taxonomy. $10^{\text {th }}$ ed. Washington: USDA-Natural Resources Conservation Service, 2010.

SORATTO, R. P.; CRUSCIOL, C. A. C. Nutrição e produtividade de grãos da aveia-preta em função da aplicação de calcário e gesso em superfície na implantação do sistema plantio direto. Revista Brasileira de Ciência do Solo, Viçosa, MG, v. 32, n. 2, p. 715-725, 2008.
TILLEY, J. M. A.; TERRY, R. A. A two-stage technique for the in vitro digestion of forage crops. Grass and Forage Science, v. 18, n.2, p. 104-111, 1963. DOI: 10.1111/j.1365-2494.1963.tb00335.x

VAN RAIJ, B. Soil fertility and fertilization. Piracicaba: Ceres, Potafos, 1991. 343 p.

VAN SOEST, P. J.; ROBERTSON, J. B.; LEWIS, B. A. Methods for dietary fiber, neutral detergent fiber and non-starch polysaccharides in relation to animal nutrition. Journal of Dairy Science, Champaign, v. 74, n. 10 , p. $3583-3597,1991$. DOI: $10.3168 /$ jds.S00220302(91)78551-2 